\title{
Photodynamic Therapy in the Healing of the Areolo-Papillary Complex after Mastectomy-Case Report
}

\author{
Maria da Glória Karan Marquetti1,2, Marcus Vinícius de Mello Pinto3, Aline Ronis ${ }^{3}$, \\ Lamara Laguardia Valente Rocha ${ }^{4}$, Julio Guilherme Silva5, Anny Chi', \\ Daniel Almeida Costa ${ }^{7}$
}

\author{
${ }^{1}$ Higher Education Center of Foz do Iguaçu-CESUFOZ, Paraná, Brazil \\ ${ }^{2}$ Biomedical Studies by Italian University Institute of Rosario-IUNIR, Santa Fe de la Vera Cruz, Argentina \\ ${ }^{3}$ Celulare Institute in Itaipava, Petropólis, Rio de Janeiro, Brazil \\ ${ }^{4}$ University of Caratinga, UNEC, Caratinga, Brazil \\ ${ }^{5}$ The Master's and PhD Program in Rehabilitation Sciences at University Center Augusto Motta-UNISUAM, Rio de Janeiro, Brazil \\ ${ }^{6}$ Marcos Thomé Institute, Ponta Grossa, Paraná, Brazil \\ ${ }^{7}$ Center Medicine School of Higher Education of Valença-CESVA/FAA, Rio de Janeiro, Brazil \\ Email: gloriamarquetti@gmail.com
}

How to cite this paper: da Glória Karan Marquetti, M., de Mello Pinto, M.V., Ronis, A., Rocha, L.L.V., Silva, J.G., Chi, A. and Costa, D.A. (2018) Photodynamic Therapy in the Healing of the Areolo-Papillary Complex after Mastectomy-Case Report. Health, 10, 326-333.

https://doi.org/10.4236/health.2018.103026

Received: March 8, 2018

Accepted: March 19, 2018

Published: March 22, 2018

Copyright $\odot 2018$ by authors and Scientific Research Publishing Inc. This work is licensed under the Creative Commons Attribution International License (CC BY 4.0).

http://creativecommons.org/licenses/by/4.0/

\section{(c) (i) Open Access}

\begin{abstract}
Some breast reconstruction surgeries after mastectomy, or even reductive mammoplasty, may evolve unexpectedly when the areolopapillary complex heals and develop dehiscences, necrosis and delayed healing. The purpose of this case report was to verify the efficacy of photodynamic therapy in wound healing of the areolopapillary complex. This was a case report of a female patient with diabetes, fibromyalgia and diagnosed with breast cancer, with necrotic areolopapillary complex, after debridement, photodynamic therapy started with clobetasol propionate associated with methylene blue and low power laser application. At the beginning of the treatment with photodynamic therapy, the wound had 6 centimeters of diameter, and after 19 sessions, the wound was closed completely with normalization of the color of the nipple. The photodynamic therapy is advancing a lot in healing of infected wounds and complex wounds. It can be said that in this case report, photodynamic therapy was fundamental for the complete healing, being considered a promising treatment and another alternative for dermatofunctional physiotherapists.
\end{abstract}

\section{Keywords}

Photodynamic Therapy, Wound Healing, Photomedicine 


\section{Introduction}

Photodynamic therapy (PDT) is a treatment for more than 40 years, and has been improved and changed in the way of performing the technique, being a combination of three fundamental factors for its realization, which are: photosensitizing drug, LED (light emitting diodes) light source or laser and the effective presence of oxygen [1].

Although it may have other applications, PDT has an approved indication for the treatment of keratinocyte skin cancer [2] [3] [4]. PDT also includes the possibility of being used in mixed infections (whatever their resistance profile as well as for combinations of bacteria, fungi, viruses and parasites) complementing conventional antimicrobial agents [5].

PDT is a therapy that may result in the decrease or disappearance of the microbial load. PDT has other important actions [6]. The stimulation of skin healing and epithelialization presents regenerative and immunoregulatory processes, increasing the hydroxyproline content, angiogenesis and improving the modulation of collagen (attenuation of degradation and mediatory remodeling) [6] [7].

Several authors describe the laser as an advanced healing tool that accelerates and optimizes the tissue repair process [8] [9]. Increased synthesis of RNA, DNA and adenosine triphosphate (ATP) is considered when the laser is used in the tissue repairment process [10] [11]. It also promotes fibrovascular proliferation [12], and has an immunological action [13] [14].

At the beginning of the last century, the treatment for breast cancer was mutilating, with radical surgeries, leaving aesthetic and functional sequelae in the patient and thus, greatly harming the psychological aspect. However, with a better understanding of the biological characteristics of breast tumors, surgical techniques and treatment became less radical [15] [16].

The current techniques aim to maintain the physiology of the gland and a good long-term form, with the lowest possible scar, aiming to maintain the sensitivity of the whole mammary complex. These techniques seek to pay attention to the pedicle responsible for the vascular supply of the areolopapillary complex [17].

There is usually sufficient skin in the mastectomy, but there is a risk of vascular involvement with skin flaps, wound dehiscences and necrosis of the areolar complex [18].

Wounds can be classified by their complexity, and can be considered simple, the one that evolves naturally for healing through three stages of inflation, cell proliferation and tissue remodeling. Or it can be considered complex, the one that affects more extensive area, that presents alteration in its natural cicatrization process, recurrent wounds that need intervention of health professionals [19] [20].

FERREIRA et al. [21], define criteria to consider a complex wound: 1) extensive tegument loss, 2) presence of local infection, 3) impairment of superficial tissues viability, 4) association with systemic diseases that hinder the semiologic 
process of tissue repair [22] [23].

Patient's age 62, female patient with diabetes, fibromyalgia and diagnosed with breast cancer in April 2013, being submitted to mastectomy without removal of the areolar complex of the right breast, with reconstitution and silicone prosthesis. In the left breast there were no nodules. She underwent chemotherapy and radiotherapy. In May 2017 the patient was to perform a mammoplasty of the left breast to improve the aesthetic aspect, however, a lump was found and removed in the surgical act of the mammoplasty. The histopathological report of this nodule was fragments of the left breast exhibiting focus of calcification free of neoplasia. She was referred to dermatofunctional physical therapy to perform postoperative manual lymphatic drainage on the 23rd of May. Ten drainage operations were performed, but the areolar complex began to present necrosis and the inferior junction of the T scar had dehiscence (Figure 1), and the patient was referred to the medical sector for debridement. After her return on June 23, 2017 she was submitted to treatment with PDT. The total treatment had a period of three months, but the wound healed in 19 days after the beginning of the use of PDT.

The treatment consisted of application of clobetazole and methylene blue propianate, applied throughout the two wounds and then applied the low power laser, every centimeter of distance throughout the wound. After the application was completed, the patient remained with the photopharmaceutical and sterile gauze was placed to protect.

A total of 19 appointments were performed until August 28, 2017. At the beginning of the treatment the nipple wound was $6 \mathrm{~cm}$ wide (Figure 2) being measured with a ruler, and at the end of the 19 visits both wounds were completely closed as shown in (Figure 3) (Table 1).

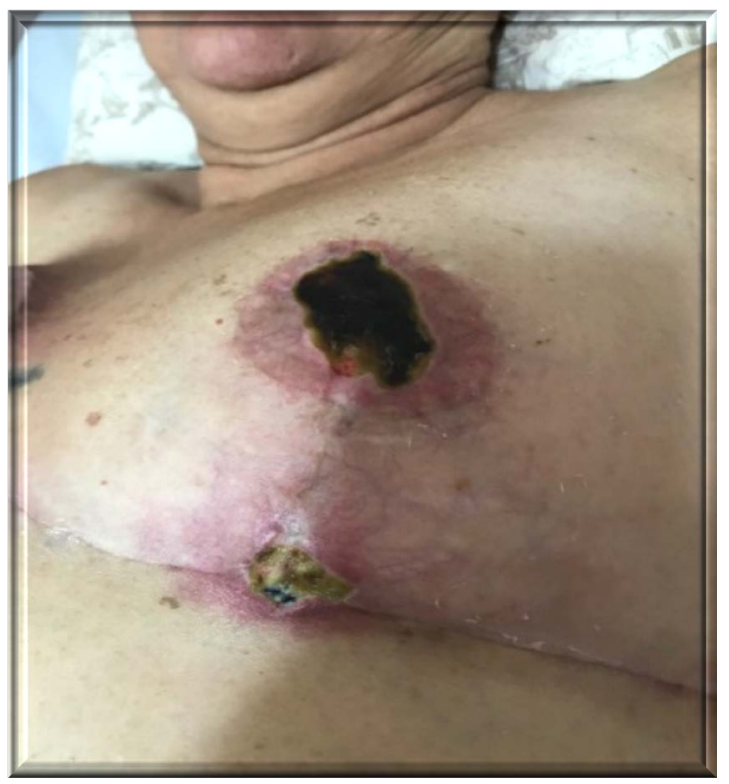

Figure 1. Necrosis of the areolar complex. 


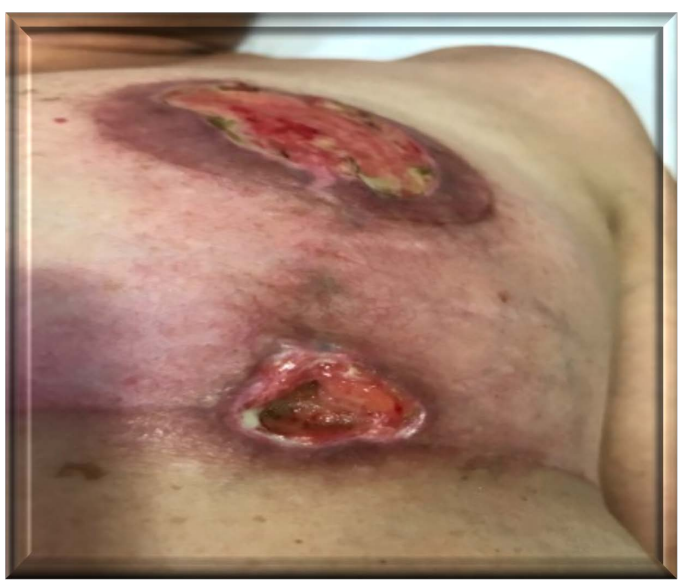

Figure 2. Breast submitted to debridement.

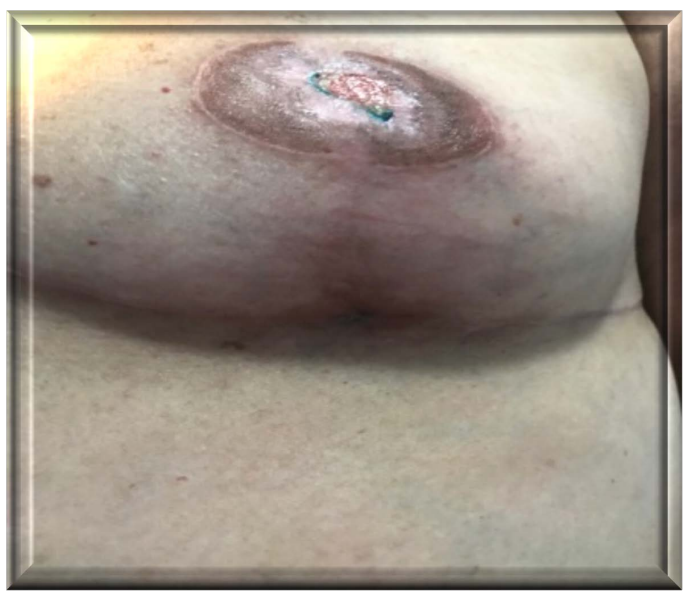

Figure 3. Fully healed breast.

Table 1. Sociodemographic characteristics of the patient.

\begin{tabular}{cc}
\hline Gender & Female \\
Age & 62 years old \\
Education & Higher \\
Occupation & Retired \\
Profession & Social worker \\
Associated pathologies & Type II diabetes and Fibromyalgia \\
Right breast cancer & April 2013 \\
Nodules without left breast neoplasia & May 2017 \\
Left breast mammoplasty & May 2017 \\
Treatment performed & PDT in wound and lymphatic drainage
\end{tabular}

After the first treatment with PDT, a reduction in wound extension and signs of neoformed tissue proliferation was observed. 
In the fourth application it was observed a significant reduction in the depth of the lesion, healing island appearance.

Regarding the clinical aspects of the lesion, after 19 consultations with PDT, the following were observed: decreased depth and total closure of the wound, the region that was injured resumed its darker coloration that is typical of the nipple, and improved the sensitivity reported by the patient. The scarred region did not show scarring fibrosis.

\section{Discussion}

Wound healing has been studied using various features and technologies, since it is a complex process involving biochemical alterations, interactions of several differentiated types of cells, matrix components [11] [24].

In this case report, the PDT and not only the laser were performed, believing that the association of a photofarmaco could lead to a faster and more efficient result in wound closure.

According to Lange (2017) [16], necrotic wounds present a decrease in local blood flow, promoting a decrease in mitochondrial respiration and causing alterations in the cell membrane, consequently reducing sodium elimination and increasing the $\mathrm{Na} / \mathrm{K}$ ratio, increasing the water inside the cell.

In this study, it was possible to observe the regeneration of the skin each day with reduction of the wound area.

In a review study on laser, the author reports that several authors postulate that the effect of the laser depends on the applied dose, wavelength and energy density according to the objectives proposed in each treated case [25] [26].

Some authors discuss the potential mechanisms of wound healing induced by PDT in relation to antimicrobial effects, as well as growing evidence that PDT itself may improve wound healing irrespective of its antimicrobial abilities. Although some effects have not yet been confirmed, it has been proposed that PDT can stimulate growth factors and an immune response [27] [28].

PDT has other actions in addition to the improvement that may result from a decrease, or disappearance, of the microbial load. It can stimulate healing and skin epithelialization through immunoregulatory and regenerative processes, such as increased hydroxyproline content, improved angiogenesis, and modulation of collagen (attenuating its degradation and mediating remodelling) [29].

As noted in the present case report, healing occurred rapidly despite the patient having diabetes, which in general presents difficulties in healing. It is also observed the improvement of the local peripheral circulation and the repolarization of the areolar complex.

\section{Conclusions}

There are few articles describing the clinical characteristics of areolar wounds post mastopexy, as well as treatments for this. We consider that this subject is of great relevance for more advanced and fast resolution approaches. 
However, there are many studies of low-power laser therapy in wound healing.

PDT has been growing as a therapy and many studies still need to be performed to prove the efficacy in infected wounds and complex wounds, especially after a re-construction as is the case in this case report.

It can be said that in this case report, the PDT was fundamental for the complete healing of the wound, and could be considered as a promising treatment.

A larger $\mathrm{n}$ is needed with randomized study, and in the near future, we will have important meta-analysis for these types of cases that we have treated.

\section{References}

[1] Pinto, M.V.M. (2011) Fototerapia-Aspectos clínicos da reabilitação. Andreoli, São Paulo.

[2] Aspiroz, C., Gilaberte, Y. and Cristóbal, P.P. (2011) Onicólisis AR, distal en un paciente anciano polimedicado resuelta con terapia fotodinâmica. Enfermedades Infecciosas y Microbiología Clínica, 29, 626. https://doi.org/10.1016/j.eimc.2011.01.014

[3] Sahu, K., Sharma, M., Dube, A. and Gupta, P.K. (2015) Topical Antimicrobial Photodynamic Therapy Improves Angiogenesis in Wounds of Diabetic Mice. Lasers in Medical Science, 30, 1923-1929. https://doi.org/10.1007/s10103-015-1784-8

[4] Pinto, N.C., Pereira, M.H.C., Tomimura, S., Magalhães, A.C., Pomerantzeff, P.M. and Chavantes, M.C. (2014) Low-Level Laser Therapy Prevents Prodromal Signal Complications on Saphenectomy Post Myocardial Revascularization. Photomedical and Laser Survey, 32, No. 6.

[5] Smol'yaninova, N.K., Karu, T.I., Fedoseeva, G.E. and Zelenin, A.V. (1991) Effects of He-Ne Laser Irradiation on Chromatin Properties and Synthesis of Nucleic Acids in Human Peripheral Blood Lymphocytes. Journal of Biomedical Science, 2, 21-126.

[6] Young, S., Bolton, P., Dyson, M., Harvey, W. and Dia-Mantopoulos, C. (1989) Macrophage Responsiveness to Light Therapy. Lasers in Surgery and Medicine, 9, 497-505. https://doi.org/10.1002/lsm.1900090513

[7] Höfling, D.B., Chavantes, M.C., Juliano, A.G., Cerri, G.G., Romao, R., Yoshimura, E.M. and Chammas, M.C. (2010) Low Level Laser Therapy in Chronic Auto Immune Thyroiditis: A Pilot Study. Lasers in Surgery and Medicine, 42, 589-596. https://doi.org/10.1002/lsm.20941

[8] Pinto, M.V.M., Sampaio, A.R., Gonçalves, R.V., Veiga, C.E.T., Rocha, L.L.V., Costa, D.A., Lopes, L.C.P., Ferreira, R.B., Valim, P.M., Cainelli, C.K.R., Sather, E.S. and Vieira, R.R.B.T. (2017) Study of Effects of Photodynamic Therapy (PDT), in Scar-Induced Skin Wounds in Rats Wistar: The New Clinical Perspective for Ulcers. Modern Research in Inflammation, 6, 1-8. https://doi.org/10.4236/mri.2017.61001

[9] Furlan, V.L.A., Sabino, M., AbLa, L.E.F., Oliveira, C.J.R., Lima, A.C., Ruiz, B.F.O. and Ferreira, L.M. (2013) Rev Quality of Life and Self-Esteem after Mastectomy in Patients Who Did or Did Not Undergo Breast Reconstruction. Revista Brasileira de Cirurgia Plástica, 28, 264-269. https://doi.org/10.1590/S1983-51752013000200016

[10] Veiga, D.F., Veiga-Filho, J., Ribeiro, L.M., Archangelo, I., Balbino, P.F., Caetano, L.V., et al. (2010) Quality-of-Life and Self-Esteem Outcomes after Oncoplastic Breast-Conserving Surgery. Plastic and Reconstructive Surgery, 125, 811-817. https://doi.org/10.1097/PRS.0b013e3181ccdac5 
[11] Bellino, S., Fenocchio, M., Zizza, M., Rocca, G., Bogetti, P. and Bogetto, F. (2011) Quality of Life of Patients Who Undergo Breast Reconstruction after Mastectomy: Effects of Personality Characteristics. Plastic and Reconstructive Surgery, 127, 10-17. https://doi.org/10.1097/PRS.0b013e3181f956c0

[12] Souza, A., Faiwichow, L., Ferreira, A.A., Simão, T.S., Pitol, D.N. and Máximo, F.R. (2011) Comparative Analysis of Mammaplasty Techniques Based on the Long-Term Effect on the Nipple-Areolar-Complex to Inframammary Crease Distance. Revista Brasileira de Cirurgia Plástica, 26, 664-669. https://doi.org/10.1590/S1983-51752011000400022

[13] Atiyeh, B.S., Bas, J. and Costagliola, M. (2012) Barreira cutânea para reconstrução mamária com prótese. Revista Brasileira de Cirurgia Plástica, 27, 630-635. https://doi.org/10.1590/S1983-51752012000400028

[14] Smaniotto, P.H.S., Galli, R., Carvalho, V.F. and Ferreira, M.C. (2010) Tratamento clínico das feridas-Curativos. Revista Médica de São Paulo, 89, 137-141.

[15] Siqueira, C.P.C.M., Filho, D.O.T., Lima, F.M., Silva, F.P., Durante, H., Dias, I.F.L., Duarte, J.L., Kashimoto, R.K. and Castro, V.A.B. (2009) Biological Effects of Light: Application of Low Power Therapy using LEDs (Light Emitting Diode) on the Healing of Venous Ulcers: A Case Report. Ciências Biológicas e da Saúde, Londrina, 30, 37-46. https://doi.org/10.5433/1679-0367.2009v30n1p37

[16] Lange, A. (2017) Fisioterapia Dermatofuncional aplicada à cirurgia plástica: Intercorrências, complicações, Avaliação e tratamento. 2nd Edition, Vitória Gráfica e Editora.

[17] Stein, E., Koehn, J., Sutter, W., Wendtlandt, G., Wanschitz, F., Thurnher, D., et al. (2008) Initial Effects of Low-Level Laser Therapy on Growth and Differentiation of Human Osteoblast-Like Cells. Wiener klinische Wochenschrift, 120, 112-117. https://doi.org/10.1007/s00508-008-0932-6

[18] Castro, J.L.F., Pinheiro, A.L.B., Werneck, C.E. and Soares, C.P. (2005) The Effect of Laser Therapy on the Proliferation of Oral KB Carcinoma Cells: An in Vitro Study. Photomedicine and Laser Surgery, 23, 586-589. https://doi.org/10.1089/pho.2005.23.586

[19] Werneck, C.E., Pinheiro, A.L.B., Pacheco, M.T.T., Soares, C.P. and Castro, J.L.F. (2005) Laser Light Is Capable of Inducing Proliferation of Carcinoma Cells in Culture: A Spectroscopic in Vitro Study. Photomedicine and Laser Surgery, 23, 300-303. https://doi.org/10.1089/pho.2005.23.300

[20] Renno, A.C.M., McDonnell, P.A., Parizotto, N.A. and Laakso, E.L. (2007) The Effects of Laser Irradiation on Osteoblast and Osteosarcoma Cell Proliferation and Differentiation in Vitro. Photomedicine and Laser Surgery, 25, 275-280. https://doi.org/10.1089/pho.2007.2055

[21] Ferreira, M.C., Tuma, J.P., Carvalho, V.F. and Kamamoto, F. (2006) Complex Wounds. Clinics, 61, 571-578.

[22] Brown, S. (2012) Clinical Antimicrobial Photodynamic Therapy: Phase II Studies in Chronic Wounds. Journal of the National Comprehensive Cancer Network, 10 , S80-S83. https://doi.org/10.6004/jnccn.2012.0182

[23] Kharkwal, J.B., Sharma, S.K., Huang, Y.Y., Dai, T. and Hamblin, M. (2011) Photodynamic Therapy for Infections: Clinical Applications. Lasers in Surgery and Medicine, 43, 755-767. https://doi.org/10.1002/1sm.21080

[24] Reinhard, A., Sandborn, W.J., Melhem, H., Bolotine, L., Chamaillard, M. and Peyrin-Biroulet, L. (2015) Photodynamic Therapy as a New Treatment Modality for Inflammatory and Infectious Conditions. Expert Review of Clinical Immunology, 11, 
637-657. https://doi.org/10.1586/1744666X.2015.1032256

[25] Bjordal, J.M., Johnson, M.I., Iversen, V., Aimbire, F. and Lopes-Martins, R.A.B. (2006) Low-Level Laser Therapy in Acute Pain: A Systematic Review of Possible Mechanisms of Action and Clinical Effects in Randomized Placebo-Controlled Trials. Photomedicine and Laser Surgery, 24, 158-168.

https://doi.org/10.1089/pho.2006.24.158

[26] Eduardo, F.P., Bueno, D.F., Freitas, P.M., Marques, M.M. and Passos, B. (2008) Stem Cell Proliferation under Low Intensity Laser Irradiation: A Preliminary Study. Lasers in Surgery and Medicine, 40, 433-438. https://doi.org/10.1002/1sm.20646

[27] Tuby, H., Maltz, L. and Oron, U. (2007) Low-Level Laser Irradiation Promotes Proliferation of Mesenchymal and Cardiac Stem Cells in Culture. Lasers in Surgery and Medicine, 39, 373-378. https://doi.org/10.1002/lsm.20492

[28] Henriques, A.C.G., Cazal, C. and Castro, J.F.L. (2010) Ação da laserterapia no processo de proliferação e diferenciação celular: Revisão da literatura. Revista do Colégio Brasileiro de Cirurgióes, 37, 295-302. http://www.scielo.br/rcbc

[29] Aspiroz, C., Sevil, M., Toyas, C. and Gilaberted, Y. (2017) Photodynamic Therapy with Methylene Blue for Skin Ulcers Infected with Pseudomonas aeruginosa and Fusarium spp. Actas Dermo-Sifiliográficas, 108, e45-e48. 